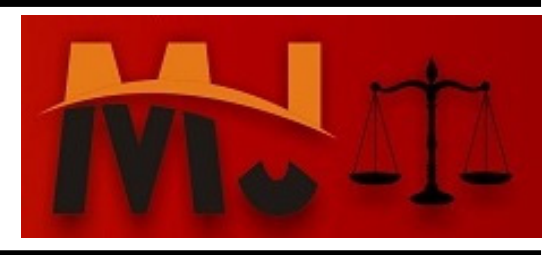

\title{
PRINSIP, ASAS DAN KAIDAH HUKUM WARIS ISLAM ADIL GENDER
}

\author{
Walim \\ Fakultas Hukum UNTAG Cirebon \\ E-mail: walimshmh7@gmail.com
}

Masuk: Maret 2017

Penerimaan: Maret 2017

Publikasi: Juni 2017

\begin{abstract}
ABSTRAK
Secara teoritis, kajian hukum kewarisan Islam dapat dilihat dari sudut pandang yang berbeda yaitu pada objek hukumnya yang berkaitan pembagian harta benda yang lebih berdimensi hukum keperdataan dan lebih dekat dalam ruang lingkup kajian Figh muamalah dan berhubungan dengan hukum antar pribadi. Dalam pandangan penulis lebih dekat pada kajian muamalah yang terbuka kemungkinan ruang ijtihad sehingga hukum Islam dapat beradaptasi dengan tuntutan zaman yang selalu berubah. Persoalan pembagian harta warisan memiliki dimensi konsep "tribalisme" dan Islam hadir untuk mendekonstruksi "tribalisme" dengan fundamen keagamaan dengan semangat egalitarianism menjadikan perempuan sebagai pribadi otonom dan bermartabat serta diakui nilai kemanusiaannya. Bagian anak laki-laki yang memperoleh bagian dua kali lipat dari bagian anak perempuan adalah bagian batas maksimal (had al-aqsa) yang tidak boleh melampaui batasan bagian maksimal itu, sekaligus larangan memberikan bagian lebih sedikit dari setengah bagian laki-laki untuk anak perempuan. Hudud Allah berupa batasan-batasan hukum menyiratkan perlunya pembagian yang sama antara lakilaki dan perempuan. Persamaan adalah adanya keserasian bagian antara batas maksimal bagi laki-laki dan batas minimal bagian perempuan sebagaimana batas-batas yang sudah dibuat Allah.
\end{abstract}

Kata Kunci: Waris Islam; Pembagian Harta Warisan; Gender; Fiqh Muamalah; Persamaan.

\begin{abstract}
Theoretically, the Islamic inheritance law can be seen from different point of view based on its object of law related to the division of property that has more dimension on civil law and more closely within muamalah Fiqh as the scope of the study and related to interpersonal law. Based on the writer's point of view, it is closer to the muamalah study which opens the possibility of ijtihad so that, Islamic law can be adapted in every period of time. The problem of inheritance division assumed the concept of 'tribalism' and Islam comes to deconstruct the "tribalism" with the fundamental religion by the egalitarianism spirit to state woman as an autonomous and dignified personal and has values. The portion of the man's share who gets twice of the girl's actually is the


maximum share (had al-aqsa) which should not exceed the maximum share of the section, as well as the prohibition of giving a share of less than half of the male portion for the girl. Allah's Hudud in the form of legal limitation indicates the necessity of equal sharing between men and women. So, the equality is the existence of the harmony from the maximum share for men to the minimum share of women as the boundaries that have been created by God.

Keywords: Islamic Inheritance; Distributional Inheritance; Gender; Fiqh Muamalah; Equality.

\section{PENDAHULUAN}

Tujuan pokok dari syari'at Islam adalah untuk merealisir cita-cita kemaslahatan manusia yang bertumpu pada nilai-nilai keadilan sosial atas dasar nilai persamaan (egalitarian) sebagai makhluk Allah. Cita-cita keadilan sosial Islam pada tataran
Namun demikian, ketentuanketentuan hukum baik dalam Al-Qur'an maupun al-Hadits sebagian besar dinyatakan dalam bentuk bahasa yang umum (mujmal) sehingga memerlukan ijtihad. $^{2}$ Oleh karena itu, sangat memungkinkan atau bahkan suatu keniscayaan akan lahirnya keragaman interpretasi atas teks-teks keagamaan. Lahirnya ragam interpretasi di kalangan umat Islam menurut Al-Qardhawi disebabkan oleh tiga faktor utama. Pertama, tabiat agama Islam sendiri yang dasar normatif-tekstualnya sangat terbuka untuk kemungkinan lahirnya berbagai interpretasi. Dengan kata lain, ragamnya interpretasi karena Al-Qur'an dan al-Hadits sendiri memberi peluang untuk itu. Kedua, tabiat manusia yaitu bahwa setiap manusia (termasuk mujtahid/mufassir) mempunyai

pula A.E Priyono, Islam Pilihan Peradaban, Shalahudin Press, Bandung, 1984, hlm. 72.

2 Ibn Rusyd, Bida yat al-Mujtahid fi Nihayat al-Muqtashid, Dar al-Ikhya al-Maktabah, Indonesia, t.th., hlm. 2. 
Walim

Jurnal Hukum Mimbar Justitia

Vol. 3 No. 1 - Juni 2017

berbagai interes dan perbedaan perspektif dalam memahami bahasa teks dan realitas konteks sosial yang melingkupinya. Ketiga, tabiat bahasa yang merupakan produk budaya, maka struktur bahasa agama (Arab) sudah barang tentu memungkinkan untuk ditafsirkan secara beragam misalnya karena mempunyai banyak makna (musytarak) atau maknanya masih umum (amm) atau sebaliknya maknanya khusus (khas). ${ }^{3}$

Ketiga faktor tersebut, kalau ditarik dalam bingkai pembumian ajaran agama berarti perlunya mempertimbangkan aspek-aspek lokal di mana hukum Islam tersebut akan dibumikan. Langkah ini diperlukan agar apapun produk hukum yang dihasilkan tidak tercerabut dari akar budaya lokal dan masyarakat menganggap bahwa hukum tersebut adalah bagian dari citacita keadilan yang hidup dan berkembang di tengah masyarakat. Ketika hukum oleh masyarakat sudah diposisikan sebagai kebutuhan, maka akan lahir kesadaran kolektif untuk komit dan konsisten terhadap produk hukum tersebut. Dengan identifikasi

3 Huzaemah Tahido Yanggo, Pengantar Perbandingan Mazhab, Logos Publishing, Jakarta, 1993, hlm. 64-65. masalah 1. Bagaimanakah Teoritis Tawaran Shahrur dan Nasr Hamid Dalam Pengembangan Hukum Waris Islam Di Indonesia? 2. Bagaimanakah Ruang Lingkup Dan Wilayah Pembaruan Hukum Islam?

\section{PEMBAHASAN}

\section{A. Pemikiran Shahrur dan Nasr Hamid Abu Zayd}

Latar belakang konstruksi pemikiran Syahrur dibangun dalam dua pokok pikiran: pertama, pandangannya terhadap realitas masyarakat kontemporer, kedua, pandangannya terhadap tradisi ulama

\section{7} terdahulu (turas). Paling tidak ada beberapa faktor yang melatarbelakangi dan membentuk cara pandang dan kerangka berfikir Syharur, Pertama, tidak adanya metode yang baku dalam menafsirkan teks keagamaan Al-Quran dan Hadis melahirkan polarisasi pemahaman/tafsir keagamaan. Kedua, adanya kecenderungan masyarakat muslim untuk merujuk khazanah klasik secara literalis tanpa mempertimbangkan dimensi historisitas, lokalitas dan setting sosiokultural masyarakat yang ada kemudian mendialogkan dengan realitas kekinian. 
Posisi pemikiran Syahrur dalam konstelasi lalu lintas dan perdebatan tafsir keagamaan adalah pada posisi tengah antara kutub literalis dan kontekstualis-sekularis yaitu Syahrur menyerukan kembali kepada al-Tanzil teks asli yang diwahyukan Allah SWT kepada Nabi Muhammad SAW dalam paradigma pemahaman yang baru. Syahrur menyerukan pemahaman AlQuran dengan prinsip "perlakukanlah Al-Quran seolah-olah Nabi Muhammad SAW meninggal kemarin. Pemahaman tersebut meniscayakan umat Islam untuk memahami Al-Quran sesuai dengan konteks ruang dan waktu para pemikir muslim hidup dan tidak terjebak dalam produk pemikiran masa lalu. Akhirnya hasil interpretasi generasi awal tidaklah mengikat bagi generasi masa kini, bahkan menurutnya generasi sekarang memiliki perangkat pengetahuan yang lebih baik untuk memahami Al-Quran dari pada generasi awal.

Sebagaimana pemikir Muslim kontemporer lainnya, seperti Fazlur Rahman, Abid al-Jabiri, Muhammad Syahrur, dan Muhammad Arkoun, Nasr Hamid Abu Zayd juga berusaha memadukan tradisi berfikir keilmuan kontemporer yang telah memanfaatkan kerangka teori dan metodologi yang digunakan oleh ilmu-ilmu sosial dan humaniora. Upaya pembaharuan (altajdid) Nasr Hamid terhadap tradisi (turats) tidak dapat dilepaskan dari konteks wacana keagamaan kontemporer, terutama di dunia Arab-Islam. Menurutnya kesadaran ilmiah terhadap tradisi akan dapat melahirkan perangkat yang efektif dalam melawan gagasan konservatisme dan merupakan prasyarat mendasar bagi keberhasilan kebangkitan dan pembaruan. Gagasan pembaruan itu diwujudkan ketika umat Islam terbingkai menurut Nasr Hamid adalah dalam peradaban teks. Oleh karena itu, menurutnya salah satu upaya mengubah pandangan umat Islam, termasuk dalam memandang perempuan adalah dengan melakukan pembacaan dan penafsiran ulang terhadap teks-teks keagamaan.

Dalam konteks ini, wacana agama menghadapi tantangan dari proses modernisasi, di mana pada tingkat sosial, ekonomi, politik, kultural, dan intelektual telah memaksa bersikap moderat atas nama pembaruan dan menjadikan Islam sebagai basis ideologinya. Tentunya fenomena ini 
tidak saja berimplikasi pada tingkat sosial, ekonomi, budaya, dan politis, tetapi juga pada teks-teks keagamaan itu sendiri. Teks lalu berubah fungsi (menjadi konsumsi sosial, politik, dan kultural) dan pembacaan teks menjadi tidak produktif (muntijah) tetapi tendensius-ideologis (mugridahtalwiniyyah). Nasr Hamid dari sisi pemikiran banyak dipengaruhi oleh para pemikir yang mengikuti trend kritik sastra sebagaimana telah disebutkan pada sejarah singkat, karier akademik dan karya-karyanya. Perspektif yang paling mendesak dalam kajian susastra (balaghoh) adalah wacana tentang majas yang menghendaki analisis historis yang independen, terutama jika dikaitkan dengan signifikansi Al-Qur'an dalam membentuk ungkapan sastra yang unggul (al-i'tibar al-baligh).

\section{B. Ketentuan Hukum Waris Dalam Al-Qur'an}

Dalam bahasa Arab, kata yang digunakan untuk menunjuk pada hak pewarisan adalah kata الارث yang secara bahasa berarti انتقال الثيء من قوم إلى قوم (berpindahnya sesuatu dari satu kaum kepada kaum lain). ${ }^{4}$

Pengertian hukum kewarisan adalah hukum yang mengatur tentang pemindahan hak pemilikan harta peninggalan (tirkah) pewaris, menentukan siapa-siapa yang berhak menjadi ahli waris dan berapa bagiannya masing-masing). Hukum kewarisan dalam Islam dikenal dengan istilah fara'idh bentuk jamak dari kata tunggal faridhah yang berarti ketentuan; hal ini karena dalam Islam bagianbagian warisan yang menjadi hak ahli waris telah dibakukan dalam AlQur'an. ${ }^{5}$

\section{9}

Ilmu mawaris atau ilmu al-faraidh termasuk ilmu yang penting dalam hukum Islam sebagaimana dikatakan Nabi dalam sebuah hadisnya:
"Belajarlah ilmu fara'idh dan ajarkanlah kepada manusia, karena sesungguhnya ilmu fara'id adalah separo dari ilmu pengetahuan". 6

4 Abdul Karim ibn Muhammad al-Lahim, alFaraidh Wizarat al-Syu'un al-Islamiyati wa al-Auqaf wa al-Da'wah wa al-Irsyad, 1421 $\mathrm{H}, \mathrm{hlm} .2$.

5 Ahmad Rofiq, Hukum Islam di Indonesia, Raja Grafindo Persada, Jakarta, 1995, hlm. 356.

6 Adapun muatan Hadits di atas adalah: تعلموا Lihat, Abu Hasan al-Daruquthni, Sunan al-Daruquthni juz 4 Bairut: Dar al-Ma'rifat, 1966, hlm. 67. 


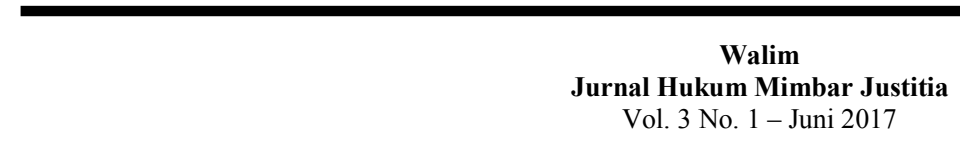

\begin{abstract}
Pelaksanaan pembagian harta warisan akan terlaksana jika telah memenuhi rukun dan sebab-sebab mewarisi. Adapun rukun waris adalah adanya orang yang meninggalkan harta warisan (mayyit), adanya orang yang mewarisi (ahli waris) dan adanya harta yang akan diwarisi. Sebab-sebab orang mendapat harta warisan adalah sebab adanya hubungan darah (nasab), sebab perkawinan dan sebab memerdekakan budak. $^{7}$
\end{abstract}

Secara normatif, pembagian harta warisan baik menyangkut siapa ahli waris dan berapa bagian masingmasingnya Al-Qur'an telah menjelaskan secara rinci dan jelas yaitu pada surat an-Nisa ayat 11, 12, 13 dan 179. Pola pembagian harta warisan antara anak laki-laki dan perempuan yang menjadi fokus kajian makalah ini adalah surat an-Nisa ayat 11 .

"Artinya: Allah mensyari'atkan bagimu tentang (pembagian pusaka untuk) anak-anakmu. Yaitu: bahagian seorang anak lelaki sama dengan bagian dua orang anak perempuan dan jika anak itu semuanya perempuan

Bandingkan dengan, Abdullah ibn Qudamah al-Maqdisi, al-Kafi fi Fiqh Ibn Hanbal juz 2, al-Maktab al-Islamy, Bairut, 1988, hlm. 125.

7 Abdul Karim ibn Muhammad al-Lahim, alFaraidh..., Op.Cit, hlm. 6-8. lebih dari dua, Maka bagi mereka dua pertiga dari harta yang ditinggalkan; jika anak perempuan itu seorang saja, Maka ia memperoleh separo harta. dan untuk dua orang ibu-bapa, bagi masing-masingnya seperenam dari harta yang ditinggalkan, jika yang meninggal itu mempunyai anak; jika orang yang meninggal tidak mempunyai anak dan ia diwarisi oleh ibu-bapaknya (saja), Maka ibunya mendapat sepertiga; jika yang meninggal itu mempunyai beberapa saudara, Maka ibunya mendapat seperenam. (Pembagian-pembagian tersebut di atas) sesudah dipenuhi wasiat yang ia buat atau (dan) sesudah dibayar utangnya. (tentang) orang tuamu dan anak-anakmu, kamu tidak mengetahui siapa di antara mereka yang lebih dekat (banyak) manfaatnya bagimu. ini adalah ketetapan dari Allah. Sesungguhnya Allah Maha mengetahui lagi Maha Bijaksana".

Substansi ayat yang menunjuk pada makna hukum (wajhu al-dilalah) pada ayat di atas adalah kalimat يوصيكم اولاد Kata ـ الله في اولادكم للأكر مثل حظ الانثيين yang merupakan inti pembahasan adalah isim yang menyatukan tentang sesuatu atau banyak baik anak laki-laki maupun anak perempuan, sehingga perlu diberikan penegasan (muqayyad) dan di sinilah fungsi kata الانثي dan الذكر seolah-olah menjadi muqayyad terhadap kata اولاد, untuk lebih memperjelas 
posisi dari makna ayat di atas bandingkan dengan ayat 176 surat alNisa:

"Artinya: dan jika mereka (ahli waris itu terdiri dari) saudarasaudara laki dan perempuan, Maka bahagian seorang saudara laki-laki sebanyak bahagian dua orang saudara perempuan."

Sebelum menyatakan kata الأكر dan الانثي terlebih dahulu dinyatakan jenis gendernya yaitu kata رجالا ونساء. Dengan memperhatikan ayat 176 surat an-Nisa ini semakin mempertegas fungsi pembatasan makna yaitu untuk menyatakan pembagian warisan didasarkan pada fungsi gender, sedangkan kata الأكر maknanya dan الانثي man tetap mengacu kepada makna pembedaan jenis laki-laki dan perempuan dalam pengertian secara biologis. $^{8}$

Dalam ayat tersebut dijelaskan bahwa bagian anak laki-laki adalah sama dengan dua anak perempuan. Ketentuan ini didasarkan pada pemikiran bahwa peran gender anak laki-laki adalah penanggungjawab

8 Nasarudin Umar, dalam, Siti Rukhaini Dzuhayatin dkk (ed.),"Kajian Kritis terhadap Ayat-ayat Gender (Pendekatan Hermeneutik)" Rekonstruksi Metodologis Wacana Kesetaraan Gender Dalam Islam, PSW UIN, Jakarta, 2002, hlm. 141-142. keluarga yaitu sebagai penanggung jawab ekonomi keluarga. Hal ini dinyatakan dalam Al-Qur'an surat AnNisa ayat 34 :

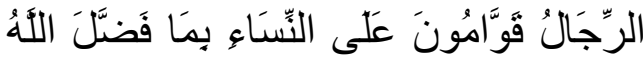

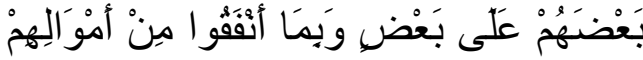

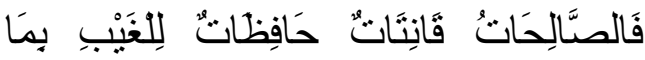

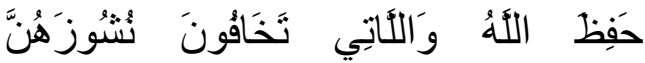

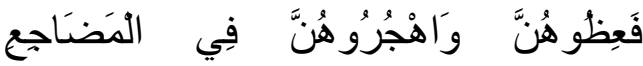

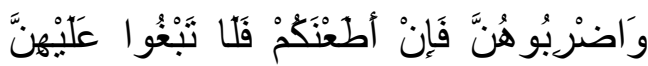

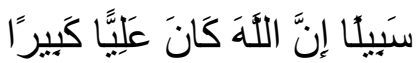

"Artinya: Laki-laki adalah pemimpin bagi kaum wanita, oleh karena Allah telah melebihkan sebagian mereka (laki-laki) atas sebagian yang lain (wanita), dan karena mereka (laki-laki) telah menafkahkan sebagian dari harta mereka. Sebab itu maka, wanita yang shalih, ialah yang ta'at kepada Allah lagi memelihara diri. Wanita-wanita yang kamu khawatirkan nusyuznya, maka nasihatilah mereka dan pisahkanlah mereka di tempat tidur mereka dan pukullah mereka. Kemudian jika mereka mnta'atimu, maka jangnlah kamu mencari-cari jalan untuk menyusahkanya. Sesungguhnya Allah Maha Tinggi lagi Maha Besar."

Para mufassir pada umumnya memberikan penafsiran pada ayat ini khususnya lafadz Qawwamun bahwa suami adalah pemimpin, pelindung, 
penanggungjawab, pendidik dan pengatur dalam konteks kehidupan rumah tangga. Bahkan ayat ini juga dipahami sebagai landasan bagi pengharaman/pembatasan perempuan untuk terjun menjadi pemimpin di wilayah publik (kepemimpinan politik). Pemaknaan atas kelebihan seorang suami atas isterinya didasarkan pada pamaknaan lafadz lain yaitu bima faddhalallah yaitu sebab Allah melebihkan kepada laki-laki. ${ }^{9}$

Menurut Nasarudin Umar dengan mengutip pendapat
Shahrur berpendapat dalam kaitan interpretasi superioritas laki-laki dengan berbagai keutamaan fasilitas hukum yang dimilikinya adalah bersumber dari tafsir ulama Fiqh yang memaksakan otoritas patriarkhis sebagai sistem sosial, meskipun sistem itu adalah warisan masyarakat pra Islam, khususnya Yahudi. ${ }^{11}$

Teori yang diajukan oleh Shahrur adalah teori batas yaitu batasan tertinggi (had al-a'la) dan batasan terendah (had al-adna). Bagian laki-laki dalam perolehan harta warisan adalah batas tertinggi/maksimal, sedangkan perolehan perempuan adalah batas terendah yang dapat bergerak ke atas sehingga sama dengan perolehan laki-laki. Argumentasi yang dibangun Shahrur adalah karena ahli waris perempuan adalah faktor peubah (al-

mendasarkan pada tafsir maudhu'i dengan menghubungkan pada ayat-ayat lain yang pada prinsipnya kata ar-Rijal tidak sematamata bermakna 'jenis kelamin laki-laki' tetapi seseorang yang dihubungkan dengan atribut sosial budaya tertentu, lebih lanjut lihat Nasarudin Umar, dalam Siti Ruhaini Dzuhayatin dkk, "Kajian Kritis terhadap Ayat-ayat Gender Pendekatan Hermeneutik", Rekonstruksi.... Op.Cit, hlm. 124-130.

11 Muhammad Shahrur, Dirasat Islamiyah Mu'ashirah: Nahwa Ushul Jadidah li Fiqh alIslamy, terj. Sahiron Syamsuddin "Metodologi Fiqh Islam Kontemporer", elSAQ Press, Yogyakarta, 2004, hIm. 349. 
mutahawwil) bagian anak laki-laki yang merupakan variable pengikut (tabi $\left.{ }^{\prime}\right){ }^{12}$

Jumlah perolehan ahli waris lakilaki akan selalu tetap, sementara jumlah perolehan ahli waris perempuan berubah-ubah sesuai dengan jumlah ahli waris anak perempuannya. Oleh karena itu, penyebutan jumlah laki-laki hanya sekali dalam ayat-ayat waris, sedangkan jumlah anak perempuan memiliki berbagai kemungkinan nilai yang sangat beragam, sejak dari satu hingga tanpa batas.

Dalam pandangan Syharur, hukum kewarisan Islam bersandar pada Al-Quran surat an-Nisa; ayat 11 dan diakhiri ayat 13. Kritik Syharur terhadap tafsir ulama klasik terkait dengan konsep hukum waris kurang dikaitkan dengan hukum wasiat. Pada saat yang sama, ulama-ulama terdahulu memaksakan penghapusan (nasakh) pada ayat-ayat wasiat pada firman Allah "al-wassiyatu lil walidain wa al aqrabin dengan mendasarkan pada hadis " $L a$ wasiya li warisin".

Mencampuradukan antara dua konsep yang berbeda yaitu al-haddu (jatah pada warisan) dan al-nashib

12 Muhammad Shahrur, Dirasat Islamiyah Mu'ashirah..., Op.Cit, hlm. 342-345. (bagian pada wasiat) pada surat al-Nisa' ayat 7 . Ayat ini dipahami sebagai ayat hukum waris, padahal menjelaskan wasiat. Menurut Syahrur istilah nashib merujuk pada bagian wasiat, sedangkan kata al-haddu merujuk pada bagian yang diterima dalam warisan.

Aspek lain yang dikritik Syahrur adalah tidak dibedakanya konsep keadilan universal pada ayat-ayat waris dan konsep keadilan spesifik pada ayatayat wasiat. Dalam pandangan Syharur, ketentuan yang bersifat umum tidak berarti menghapus yang bersifat khusus. Kritik Syahrur yang lain terkait dengan pemaknaan-pemaknaan ulama terdahulu adalah terkait dengan makna lafadz al-walad yang dipahami anak laki-laki yang berkonsekuensi pada hukum bahwa anak laki-lakilah yang menjadi sebab terhalangnya atau tertutupnya suatu warisan pada pihak lain karena pemahaman seperti ini adalah reduksi makna yang nyata terhadap firman Allah "Yusikumullahu fi auladikum li al-dhakari mitslu haddhil untsayain". Menurutnya, terma al-walad mencakup kedua jenis kelamin baik laki-laki maupun perempuan.

Menurut Syahrur, ayat-ayat tentang waris diturunkan dan 
Walim

Jurnal Hukum Mimbar Justitia

Vol. 3 No. 1 - Juni 2017

diberlakukan bagi seluruh umat manusia secara kolektif, bukan untuk pribadi atau golongan tertentu. Ayatayat tentang waris menggambarkan aturan universal yang ditetapkan berdasarkan aturan matematis (teori himpunan/teknik analisis/analisis matematis) dan empat operasional ilmu hitung (penjumlahan, pengurangan, perkalian dan pembagian). Sedangkan ayat tentang wasiat tidak memberikan ketentuan hukum hitungan tertentu, tetapi Allah hanya memberikan dorongan untuk memberikan prioritas sasaran wasiatnya kepada orang yang paling berhak menerima yaitu keluarga dekat yang miskin dan membutuhkan. Wasiat lebih dahulu ditunaikan sebelum warisan karena wasiat menyangkut kepentingan pribadi dan memiliki efektifitas dalam distribusi harta. ${ }^{13}$

\section{Pendapat Muhammad Shahrur} di atas juga parallel dengan pendapat Nasr Hamid Abu Zaid dengan menyatakan bahwa bagian bagi perempuan adalah bagian pokok (alashl) yang akan mempengaruhi persentase bagian laki-laki. Oleh karena itu memungkinkan ada dinamika

13 Muhammad Syharur, Metodologi Fiqih....Op.Cit, hlm. 323-324. pembagian warisan dalam Islam dengan mempertimbangkan realitas sosial yang berkembang bergerak pada terbukanya ruang akses yang sama antara laki-laki dan perempuan, maka batasan bagian perempuan dari batas minimal ke maksimal menjadi dimungkinkan dengan berpegang pada tujuan universal syariat Islam yaitu upaya penciptaan nilai keadilan. Hal ini juga untuk mendekatkan idealisme Islam untuk mempertautkan antara horizon kesetaraan religius (musawah diniyah) dengan horizon kesetaraan sosial (musawah ijtima'iyyah) secara padu sesuai dengan peran gender laki-laki dan perempuan. ${ }^{14}$

\section{Dalam pandangan Nasr Hamid}

Abu Zayd, konsep hukum waris Islam bertumpu pada konsep dekonstruksi kultural masyarakat para Islam yang tidak memberikan apresiasi manusiawi kepada perempuan dan orang-orang lemah yakni anak-anak kecil. Hak waris pada waktu itu hanya dimiliki oleh kaum laki-laki yang mampu berperang, sedangkan perempuan tidak memiliki

14 Nasr Hamid Abu Zaid, Dhawair al-Khauf: Qira'ah fi Khithab al-Mar'ah, terj. Moh Nur Ichwan, Dekonstruksi Gender: Kritik Wacana Perempuan dalam Islam, PSW UIN Yogyakarta, Yogyakarta, 2003, hlm. 207211. 
hak warisan sedikitpun. Bahkan dalam tradisi masyarakat tertentu, anak-anak perempuan dikubur hidup-hidup dan memperkenankan seorang perempuan yang ditinggal mati suaminya untuk diwariskan sebagaimana benda.

Kehadiran Islam memberikan spirit kemanusiaan baru bagi perempuan dengan memberi hak mewarisi harta peninggalan bapak atau suaminya. Tawaran revolusi kebudayaan dengan mendekonstruksi sistem nilai yang mensubordinasikan perempuan pada awalnya berat diterima oleh muslim awal. Keyakinan kaum muslim awal dalam soal waris mendasarkan pada prinsip "Kita tidak memberikan warisan kepada orang yang tidak bisa menunggang kuda, tidak kepayahan dan tidak melukai musuh". ${ }^{15}$

Dalam pandangan Nasr Hamid, bagian anak laki-laki yang memperoleh bagian dua kali lipat dari bagian anak perempuan adalah bagian batas maksimal (had al-aqsa) yang tidak boleh melampaui batasan bagian maksimal itu, sekaligus larangan memberikan bagian lebih sedikit dari setengah bagian laki-laki untuk anak perempuan. Hudud Allah berupa

15 Ibid., hlm. 207-208. batasan-batasan hukum menyiratkan perlunya pembagian yang sama antara laki-laki dan perempuan. Persamaan adalah adanya keserasian bagian antara batas maksimal bagi laki-laki dan batas minimal bagian perempuan sebagaimana batas-batas yang sudah dibuat Allah. ${ }^{16}$

Nasr Hamid Abu Zayd
mengkritik para penafsir teks yang
terpenjara oleh dan makna literal kata
hudud/batasan normatif teks yang tidak
boleh dilanggar makna teksnya. Dalam
pandangan Nasr Hamid Abu Zayd,
dengan menggunakan teori matematika kontemporer bahwa "batas" itu seperti gerakan diantara dua titik. Titik pertama adalah titik terbawah, sedangkan titik yang lain adalah titik teratas. Selanjutanya Nasr Hamid Abu Zayd menyatakan bahwa pewarisan perempuan yang setengah bagian dari laki-laki adalah batas minimal yang dapat bergerak ke atas sampai batas sama dengan bagian laki-laki. Artinya, larangan Al-Qur'an dalam masalah ini dan juga dalam masalah lain terhadap perbuatan melampaui batas-batas (hudud) Allah adalah larangan terhadap perbuatan melampaui batas minimal ke

16 Ibid., hlm. 211. 
bawah. Larangan ini tidak berkaitan dengan gerakan dari bawah (batas minimal) menuju ke atas sehingga batas persamaan pembagian. ${ }^{17}$

Menurut Nasr Hanid, persoalan pembagian harta warisan memiliki dimensi konsep "tribalisme” dan Islam hadir untuk mendekonstruksi "tribalisme" dengan fundamen keagamaan dengan semangat egalitarianism menjadikan perempuan sebagai pribadi otonom dan bermartabat serta diakui nilai kemanusiaanya.

\section{Refleksi Teoritis Tawaran}

dalam pengembangan Hukum Waris Islam di Indonesia

Agama dan keadilan gender dewasa ini menjadi salah satu isu penting yang diperbincangkan oleh semua elemen masyarakat termasuk kaum agamawan. Arus modernitas meski menciptakan perubahanperubahan cara pandang tentang perempuan, tetapi tidak sepenuhnya berperan mengikis perlakuan diskriminatif terhadap kaum perempuan. Realitas ketimpangan gender ini tidak hanya dialami bangsa

17 Ibid., hlm .287
Indonesia tetapi juga fenomena umum bangsa-bangsa di dunia yang tergambar dari banyaknya regulasi yang dibuat oleh Negara justru bias gender. ${ }^{18}$

Literatur klasik Islam pada umumnya disusun di dalam perspektif budaya masyarakat androsentris, di mana laki-laki menjadi ukuran segala sesuatu (man is the measure of all things). Literatur itu hingga kini masih diterima sebagai "kitab suci" ketiga setelah Al-Qur'an dan hadits. Kitabkitab tafsir dan Fiqh yang berjilid-jilid, yang disusun ratusan tahun lalu kini terus dicetak ulang, bahkan diantaranya melebihi kitab-kitab kontemporer. Literatur-literatur klasik Islam, kalau diukur di dalam ukuran modern, banyak diantaranya dapat dinilai sangat bias gender. Para penulisnya tentu tidak dapat disalahkan karena ukuran keadilan gender (gender equality) menggunakan paradigma dan persepsi relasi gender menurut kultur masyarakatnya. Mengkaji literatur klasik tidak dapat dipisahkan dengan rangkaian kesatuan yang koheren terutama antara penulis dan background sosial budayanya. Di sinilah perlunya

18 Husein Muhammad, Perempuan, Islam dan Negara, Qalam Nusantara, Yogyakarta, 2016, hlm. 119. 
metode hermeneutika sebagai model pembacaan teks secara tepat dan tidak tercerabut dari makna konteksnya.

Seorang pembaca teks harus mampu masuk ke dalam lorong masa silam, seolah-olah sezaman dan akrab dengan sang penulis teks, memahami kondisi objektif geografis dan latar belakang sosial budayanya, karena setiap penulis teks adalah anak zamannya. Setelah itu si pembaca sudah mampu melakukan apa yang disebut $\mathbf{W}$.

Dilthey sebagai verstehen, yaitu memahami dengan penuh penghayatan terhadap teks, ibarat sang pembaca keluar dari lorong waktu masa silam, lalu mengambil kesimpulan. ${ }^{19}$

Pada bagian lain Nasarudin Umar berusaha memetakan peta intelektual Timur Tengah tempat di mana risalah Islam pertama kali diajarkan kepada umat manusia. Menurutnya, maskulinisasi epistemologi sudah berlangsung lama di kawasan Timur-Tengah. Jauh sebelum Al-Qur'an diturunkan, dunia epistemologi sudah

19 Nasarudin Umar, dalam Siti Ruhaini Dzuhayatin dkk, "Metode Penelitian Berperspektif Gender tentang Literatur Islam", Rekonstruksi Metodologis Wacana Kesetaraan Gender dalam Islam, PSW IAIN Sunan Kalijaga-McGill-ICIHEF, Pustaka Pelajar, Yogyakarta, 2002, hlm. 85-86. dipengaruhi kosmologi, mitologi dan peradaban kuno yang cenderung misoginis. Citra perempuan di kawasan ini sangat buruk. Beberapa mummi perempuan ditemukan di Mesir menggunakan celana dalam besi yang digembok dan bersepatu besi yang berat dan berukuran kecil untuk membatasi perjalanan perempuan. Mitologi Yunani menggambarkan perempuan sebagai iblis betina (female demon), yang selalu mengumbar nafsu. Tradisi YahudiKristen (Judeo-Christianity) memojokkan perempuan sebagai penyebab dosa warisan dalam drama kosmik, peradaban Sasania-Zoroaster menyembunyikan perempuan menstruasi di goagoa gelap yang jauh dari perkampungan, dan peradaban Hindu yang memprabukan (membakar hiduphidup) para isteri di samping suaminya yang meninggal.

Citra diri seorang perempuan dalam khazanah tafsir klasik masih bias dengan titik sentuh penafsiran yang bias gender dengan memosisikan perempuan sebagai makhluk yang inferior, lemah dan mewarisi kejahatan. Dalam pandangan Amina Wadud para penafsir lebih melihat perbedaan esensial laki-laki dan perempuan dari 
segi penciptaannya, kapasitas dan fungsinya dalam masyarakat dan ganjaran yang harus diterima olehnya di hari akhir nanti. Konsekuensi logis dari interpretasi yang bias ini menghasilkan satu stigma bahwa perempuan tidak pantas memikul tugas-tugas tertentu atau peranan dalam berbagai bidang di masyarakat (public domain) seperti dalam hal kepemimpinan politik. ${ }^{20}$

Dengan demikian, interpretasi teks agama menjadi salah satu faktor determinan terbangunnya ideologi patriarki dengan menempatkan laki-laki sebagai realitas/entitas yang unggul (superior). Salah satu yang lebih mengkhawatirkan lagi adalah hasil interpretasi teks agama itu oleh sebagian muslim dianggap sebagai teks agama itu sendiri sehingga dianggap sakral, mutlak dan final. Padahal hasil interpretasi teks itu pada dasarnya adalah relatif dan bersifat dinamis sesuai dengan watak tafsir itu sendiri yang selalu bergerak sesuai dengan ritme perubahan ruang dan waktu. ${ }^{21}$

20 Amina Wadud Muhsin, "Al-Qur'an dan Perempuan" dalam Charles Kurzman (ed) Wacana Islam Liberal Pemikiran Islam Kontemporer tentang Isu-isu Global, Paramadina, Jakarta, 2003, hlm. 193.

21

Untuk membedakan antara teks dan hasil interpretasi terhadap teks, Amin Abdullah
Normatifitas teks hakikatnya netral dan responsif gender, tetapi historisitas penafsiran terhadap teks justru seringkali bias gender dan mendistorsi pesan humanisme teks itu sendiri.

Dalam upaya pembacaan teks keagamaan yang responsif gender khususnya terkait dengan hukum pembagian harta warisan tawaran Muhammad Syahrur dan Nasr Hamid Abu Zayd sangat signifikan untuk dicermati. Baik Syharur maupun Nasr mencoba memahami teks tidak melepaskan dari akar historisnya dan selalu didialogkan dengan konteks sosial sekarang ini. Dialektika teks dan konteks menjadi landasan yang padu dalam melakukan interpretasi.

Pandangan diskriminatif terhadap perempuan dalam teks klasik bahkan teks kontemporer sekalipun mudah dijumpai yang menempatkan

dalam kata pengantar bukunya Studi Agama Normativitas atau Historisitas membuat satu rumusan pembedaan dengan menyebut Islam Normatif dan Islam Historis. Islam Normatif adalah akumulasi doktrin Islam yang ada di dunia teks sehingga ia sacral dan kebenarannya mutlak. Hasil interpretasi terhadap teks disebut Islam Historis yaitu Islam yang dipahami dan dipraktikkan dalam sejarah tertentu sehingga bersifat relatif dan dinamis. Amin Abdullah, Studi Agama Normativitas atau Historisitas, Pustaka Pelajar, Yogyakarta, 1996, hlm. 5-6. 
Walim

Jurnal Hukum Mimbar Justitia

Vol. 3 No. 1 - Juni 2017

perempuan secara teo-kosmologis

diposisikan sebagai makhluk kelas dua.

Stereotipe terhadap perempuan

misalnya dalam Tafsir At-Thabari jelas

sekali tergambar terkait dengan drama

kosmis kejatuhan Nabi Adam dari

sorga yang disebabkan oleh Hawa

isterinya. Oleh karena itu, Hawa

sebagai wakil perempuan diposisikan

sebagai makhluk yang kehadiranya

sebagai sumber fitnah dalam

kehidupan. $^{22}$

Membincangkan

upaya

reinterpretasi hukum waris dalam Islam secara teoritis dan metodologis sebagai sesuatu yang dapat dipertanggungjawabkan. Secara material, hukum kewarisan lebih dominan unsur mu'amalah-nya karena bersinggungan langsung dengan hukum perdata. ${ }^{23}$ Oleh karena itu, sangat memungkinkan untuk dilakukan ijtihad baru dengan mempertimbangkan dimensi lokalitas budaya di mana hukum tersebut akan diaplikasikan. Dalam hal hukum mu'amalah umat Islam diberi

22 KH. Husein Muhammad, Adnan Mahmud (Ed.), "Tafsir Gender dalam Pemikiran Islam Kontemporer" dalam Pemikiran Islam Kontemporer di Indonesia, Pustaka Pelajar, Yogyakarta, 2005, hlm. 103-104.

23 Munawwir Sadzali, Islam Realitas Baru dan Orientasi Masa Depan, UI Press, Jakarta, 1998, hIm. 23. keleluasaan untuk berijtihad dengan pendekatan rasional dan mempertimbangkan aspek sosiologis. Hal ini berbeda dengan hukum peribadatan yang dilarang untuk diperbaharui (modifikasi) karena bersifat tauqifi dan ta'abuddi sebagai bagian dari agama yang bersifat dogmatis.

Memposisikan hukum waris sebagai bidang mu'amalah, maka yang perlu ditangkap bukan semata-mata ketentuan positif bagian masing-masing ahli waris tetapi jiwa dari ayat ini yaitu pembagian harta warisan secara adil. Formulasi bagian-bagian warisan dapat ditempatkan sebagai instrumen/wasilah untuk mencapai ghayah (final goal) dari ketentuan hukum tertentu. Konsep dasar ghayah kapanpun, di manapun, pada setting budaya apapun tidak akan berubah karena itu merupakan inti syari'ah, sedangkan alat pencapaian ghayah (wasilah) adalah sesuatu yang bersifat particular dan oleh karenanya dapat berubah sesuai dengan tuntutan sosial dan dinamika zaman yang selalu berubah.

Menurut

Syafrudin

Prawiranegara, dalam ilmu hukum terdapat dua sifat hukum yaitu compulsory law (dwingend recht) yaitu 
hukum yang berlaku secara mutlak dan voluntary law (vrijwillig recht) yaitu hukum yang berlaku kalau yang berkepentingan tidak menggunakan alternatif-alternatif lain yang tersedia. Menurutnya, ketentuan pembagian warisan sebagaimana dijelaskan dalam surat an-Nisa ayat 11 tergolong hukum yang voluntary law, yaitu yang berkepentingan dapat mengelakkan berlakunya hukum yang bersangkutan dengan mengambil tindakan-tindakan lain yang sah menurut hukum yang berlaku. $^{24}$

Upaya reinterpretasi hukum waris dalam Islam ini secara metodologis dapat dicari sandaran metodologisnya dengan melihat ijtihad-ijtihad sahabat Umar ibn Khattab yang seringkali melahirkan polemik di kalangan sahabat. Banyak kasus ijtihad Umar ibn Khattab yang secara eksplisit bertentangan dengan makna teks karena banyak memahami teks dengan berpegang pada makna konteksnya dengan cara menggali dasar filosofi sebuah ayat. Beberapa kasus menunjukkan bahwa dalam berijtihad Umar ibn Khattab mendasarkan pada pertimbangan-pertimbangan maslahat

24 Ibid., hlm. 31-32. sebagai inti dari ajaran Islam Maslahat dalam hukum waris Islam adalah keadilan. Oleh karena itu, spirit dasar dari hukum waris Islam adalah pembagian harta secara adil. Nilai keadilan manusia secara fitrah adalah keadilan yang terpancar dari Tuhan, sebab Tuhan adalah theophany kebebasan Tuhan. Menurut Hazairin, nilai dasar keadilan secara prinsip di alam idea Al-Qur'an bersifat immutable, sedangkan dunia fakta selalu berubah dan merupakan rangkaian kejadian temporal menuju nilai-nilai eternal. ${ }^{25}$

Agar hukum Islam tetap aktual untuk mengatur kehidupan umat Islam di masa kini, diperlukan hukum Islam dalam bentuknya yang baru dan tidak mesti mengambil alih semua Fiqh yang lama. Hal ini menghendaki adanya usaha tajdid atau reformulasi Figh. Di antara caranya adalah dengan memaknai kembali dalil syara yang menjadi rujukan para mujtahid tempo dulu. Usaha reaktualisasi hukum Islam melalui reformulasi Fiqh telah berlangsung di dunia Islam semenjak akhir abad XIX dan semakin terlihat

25 Abdul Ghofur Anshori, Filsafat Hukum Kewarisan Islam, UII Press, Yogyakarta, 2015, hlm. 191. 
pada awal abad XX yang terus berlangsung hingga saat ini. ${ }^{26}$

\section{Bahasan Ruang Lingkup dan Wilayah Pembaruan Hukum Islam}

Adapun berkaitan dengan ruang lingkup dan wilayah mana pembaruan hukum Islam dapat dilakukan, memang menjadi perdebatan di antara para ahli hukum Islam, karena hal itu terkait dengan wilayah hukum yang mungkin dapat dilakukan ijtihad. Menurut Amin Abdullah, wilayah ijtihad atau tajdid mestinya tidak terbatas pada persoalanpersoalan hukum agama atau hukumhukum Fiqh, tetapi mestinya harus diperluas pada al-'ulum al-kauniyah dan al-hayah al-insaniyah pada umumnya. Oleh karenanya, ruang gerak tajdid dan ijtihad tidak hanya terfokus pada wilayah hukum saja, tetapi juga masuk pada soal-soal kemanusiaan pada umumnya. Menurutnya, cara kerja dan produk ijtihad selama ini terkesan bersifat reaktif dan hanya berfungsi legitimatif tidak proaktif. ${ }^{27}$

26 Amir Syarifudin, Ushul Fiqh 2, Logos, Jakarta, 1999, hlm. 253-254.

27 M. Amin Abdullah, Dinamika Islam Kultural, Pemetaan atas Wacana Islam Kontemporer, Mizan, Bandung, 2000, hlm. 165-166.
Menurut Subkhi Mahmasani, peluang untuk melakukan pembaruan hukum Islam melalui upaya pembaruan hanya menyangkut hal-hal yang berkaitan dengan masalah-masalah mu'amalah keduniawian yang didasarkan pada prinsip kemaslahatan. Pada wilayah ibadah/'ubudiah, maka ketentuan normatifnya jelas dan rinci sehingga berlaku untuk selamanya. Oleh karena itu, perubahan waktu dan tempat ataupun berubahnya keadaan tidak ada artinya bagi soal ibadah. ${ }^{28} \mathrm{Hal}$ ini paralel dengan pendapat Al-Syatibi yang menyatakan bahwa hukum dalam wilayah ibadah bersifat ta'abbudy (dogmatis), sedangkan dalam hukum muamalah bersifat ma'qul al-ma'na dalam arti dapat dilakukan rasionalisasi melalui kerja-kerja ijtihad. ${ }^{29}$

Gagasan pembaruan hukum waris Islam yang berujung pada perubahan formula pembagian harta warisan sudah

28 Subkhi Mahmasani, Filsafat Hukum Islam, alih bahasa A. Soejono, PT Al-Ma'arif, Bandung, 1976, hlm. 118-119, lihat pula, Hasbi Ash-Shiddiqy, Pengantar IImu Fiqh, Bulan Bintang, Jakarta, 1985, hlm. 194.

29 Al-Syatibi menyatakan dalam kitabnya alMuwafaqat:

اللإل $\square$

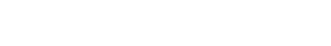

Lihat, Al-Syatibi, al-Muwafaqat fi Ushul alAhkam, Dar al-Fikr, Bairut, $1314 \mathrm{H}, \mathrm{hlm}$. 221. 
Walim

Jurnal Hukum Mimbar Justitia

Vol. 3 No. 1 - Juni 2017

tentu akan melahirkan persoalan metodologis terutama terkait dengan konsep ayat qath'y ad-dalalah (pasti penunjukan maknanya) dan dzanny addalalah (tidak pasti penunjukan maknanya) dalam Al-Qur'an yang secara keilmuan merupakan konsep yang sudah mapan dalam kancah kajian ushul Figh. Dengan demikian, pesan moral yang dibawa dari gagasan pembaruan ini secara tidak langsung juga telah mendekonstruksi konsep qot'y dan dzanny dan mengganti dengan konsep relatifis.

Tawaran gagasan teoritis Syharur dan Nasr Hamid Abu Zayd terkait dengan interpretasi teks hukum kewarisan Islam dalam konteks pengembangan hukum kewarisan Islam memiliki relevansi dengan diskursus perlunya menghadirkan formulasi hukum kewarisan di Indonesia. Dalam pandangan Nasarudin Umar, Gagasan Shahrur dengan teori batasnya dapat menjadi alternatif model pembaharuan hukum keluarga Islam dalam bidang hukum kewarisan di Indonesia. ${ }^{30}$

30 Nasarudin Umar, "Hukum Keluarga Kontemporer di Negara-negara Muslim", Makalah Seminar Nasional Hukum Materiil Peradilan Agama antara Cita, Realitas dan Harapan, Hotel Red Top Jakarta, 19 Februari 2010, hlm. 14-15.
Memposisikan kajian hukum waris Islam dalam kategori fikih muamalah menjadikan diskursus hukum kewarisan masuk pada area hukum yang bersifat ijtihadiyah. Pengaturan bagianbagian ahli waris yang bersifat eksak dan limitatif bukan berarti menutup ruang gerak ijtihad. Banyak preseden historis yang bisa dijadikan pijakan ijtihad-ijtihad kreatif-inovatif hukum kewarisan Islam di Indonesia dengan mempertimbangkan lokalitas nilai keadilan kultural Indonesia berdialog dengan keadilan universal pesan-pesan ayat suci waris. Dialog kreatif antara nilai-nilai lokal Indonesia dan universalitas hukum kewarisan dalam konteks Indonesia akan melahirkan formulasi hukum kewarisan Islam Indonesia yang berpijak pada universalitas teks tanpa tercerabut dari akar kultural Indonesia.

\section{PENUTUP}

Secara teoritis, kajian hukum kewarisan Islam dapat dilihat dari sudut pandang yang berbeda yaitu pada obyek hukumnya yang berkaitan pembagian harta benda yang lebih berdimensi hukum keperdataan dan lebih dekat dalam ruang lingkup kajian Fiqh 
muamalah dan berhubungan dengan hukum antar pribadi. Dengan mempertimbangkan kerangka berfikir seperti ini, maka kajian hukum kewarisan Islam terbuka ruang untuk dilakukan ijtihad dan modifikasimodifikasi hukum. Dalam pandangan penulis lebih dekat pada kajian muamalah yang terbuka kemungkinan ruang ijtihad sehingga hukum Islam bisa beradaptasi dengan tuntutan zaman yang selalu berubah.

Menurut Syahrur, ayat-ayat tentang waris diturunkan dan diberlakukan bagi seluruh umat manusia secara kolektif, bukan untuk pribadi atau golongan tertentu. Ayatayat tentang waris menggambarkan aturan universal yang ditetapkan berdasarkan aturan matematis (teori himpunan/teknik analisis/analisis matematis) dan empat operasional ilmu hitung (penjumlahan, pengurangan, perkalian dan pembagian). Untuk memahami hukum dan aturan tentang pembagian harta warisan diperlukan ilmu bantu yaitu: teknik analisis (alhandasah al-tahliliyah), analisa matematis (al-tahlil al-riyadhi), teori himpunan (al-majmuat), konsep variable pengikut (al-tabi') dan variabel peubah

(al-mutahawwil)

dalam matematika.

Menurut Nasr Hanid, persoalan pembagian harta warisan memiliki dimensi konsep 'tribalisme” dan Islam hadir untuk mendekonstruksi tribalisme dengan fundamen keagamaan dengan semangat egalitarianism menjadikan perempuan sebagai pribadi otonom dan bermartabat serta diakui nilai kemanusiannya. Dalam pandangan Nasr Hamid, bagian anak laki-laki yang memperoleh bagian dua kali lipat dari bagian anak perempuan adalah bagian batas maksimal (had al-aqsa) yang tidak boleh melampaui batasan bagian maksimal itu, sekaligus larangan memberikan bagian lebih sedikit dari setengah bagian laki-laki untuk anak perempuan. Hudud Allah berupa batasan-batasan hukum mengisyaratkan perlunya pembagian yang sama antara laki-laki dan perempuan. Persamaan adalah adanya keserasian bagian antara batas maksimal bagi laki-laki dan batas minimal bagian perempuan sebagaimana batas-batas yang sudah dibuat Allah.

Dalam upaya pembacaan teks keagamaan yang responsif gender khususnya terkait dengan hukum 
pembagian harta warisan tawaran

Muhammad Syahrur dan Nasr

Hamid Abu Zayd sangat signifikan untuk dicermati. Baik Syharur maupun

Nasr Hamid mencoba memahami teks tidak melepaskan dari akar historisnya dan selalu didialogkan dengan konteks sosial sekarang ini.

\section{DAFTAR PUSTAKA}

\section{A. Buku}

A. Zaki Yamani, al-Syari'ah alKhalidah wa Musykilat al-'Ashr, alih bahasa Mahyuddin Syaff, PT. Al-Ma'arif, Bandung, 1986.

A.E Priyono, Islam Pilihan Peradaban, Shalahudin Press, Bandung, 1984.

Abdul Karim ibn Muhammad al-Lahim, al-Faraidh, Wizarat al-Syu'un alIslamiyati wa al-Auqaf wa alDa'wah wa al-Irsyad, $1421 \mathrm{H}$.

Abu Hasan al-Daruquthni, Sunan alDaruquthni juz 4, Dar al-Ma'rifat, Bairut, 1966.

Ahmad Rofiq, Fiqh Mawaris, Rajawali Press, Jakarta, 1993.

Al-Syatibi, al-Muwafaqat fi Ushul alAhkam, Dar al-Fikr, Bairut, 1314 $\mathrm{H}$.

Amina Wadud Muhsin, "Al-Qur'an dan Perempuan" dalam Charles Kurzman (ed) Wacana Islam Liberal Pemikiran Islam
Kontemporer Tentang Isu-Isu Global Paramadina, Jakarta, 2003.

Hasbi Ash-Shiddiqy, Pengantar Ilmu Fiqh, Bulan Bintang, Jakarta, 1985.

KH. Husein Muhammad, "Tafsir Gender dalam Pemikiran Islam Kontemporer" dalam Pemikiran Islam Kontemporer di Indonesia, Adnan Mahmud (Ed.) Pustaka Pelajar, Jogjakarta, 2005.

Muhammad Shahrur, Dirasat Islamiyah Mu'ashirah: Nahwa Ushul Jadidah li Fiqh al-Islamy, terj. Sahiron Syamsuddin "Metodologi Fiqh Islam Kontemporer" elSAQ Press, Yogyakarta, 2004.

Nasr Hamid Abu Zaid, Dhawair alKhauf: Qira'ah fi Khithab alMar'ah, terj. Moh Nur Ichwan, Dekonstruksi Gender: Kritik Wacan Perempuan dalam Islam, PSW UIN Yogyakarta, Yogyakarta, 2003.

Siti Rukhaini Dzuhayatin dkk. (ed), Rekonstruksi Metodologis Wacana Kesetaraan Gender Dalam Islam, PSW UIN Jakarta, 2002.

Subkhi Mahmasani, Filsafat Hukum Islam, alih bahasa A. Soejono, PT Al-Ma'arif, Bandung, 1976. 